\title{
Comparative Ontogeny of the Digestive Tract in Sharpsnout Sea Bream Diplodus puntazzo Cetti and Common Pandora Pagellus erythrinus L.
}

\author{
Valeria Micale $^{*}, 1$ and Ugo Muglia ${ }^{2}$ \\ ${ }^{I}$ National Research Council, Institute for Marine Coastal Environment (CNR-IAMC), Messina, Italy \\ ${ }^{2}$ Department of Morphology, Biochemistry, Physiology and Animal Production, Faculty of Veterinary Medicine, \\ University of Messina, Italy
}

\begin{abstract}
The ontogeny of the alimentary tract and its associated structures (liver, pancreas, gall bladder) was compared between sharpsnout sea bream Diplodus puntazzo and Pagellus erythrinus and some differences were highlighted. The first goblet cells appeared earlier in sharpsnout seabream (5-7 DAH) and later in common pandora (9-11 DAH), as well as taste buds which appeared at $11 \mathrm{DAH}$ in sharpsnout seabream and at $17 \mathrm{DAH}$ in common pandora. On the contrary, stomach segmentation in a cardiac, fundic and pyloric portions was more precocious in common pandora than in sharpsnout seabream, although gastric glands were formed almost simultaneously. Early caecal development was much more precocious in sharpsnout seabream (10 DAH) than in common pandora (22 DAH). At 3 DAH in sharpsnout seabream and later (10 DAH) in common pandora, primordial mucosal folding of intestine began, which appeared well developed in the anterior portion, by $22 \mathrm{DAH}$ in common pandora and by $28 \mathrm{DAH}$ in sharpsnout seabream. The functional meanings of these aspects were discussed comparatively.
\end{abstract}

Keywords: Digestive system, Pagellus erythrinus, Diplodus puntazzo, ontogeny.

\section{INTRODUCTION}

The organogenesis of the digestive system has been investigated in a number of commercially valuable finfish species, including the halibut Hippoglossus hippoglossus L. [1], European turbot Scophthalmus maximus L. [2], cod Gadus morhua L. [3], the Dover and Senegal soles Solea solea L. and Solea senegalensis Kaup [4, 5], gilthead seabream Sparus aurata L. [6, 7], haddock Melanogrammus aeglefinnus L. [8], clownfish Amphiprion percula [9], white seabream Diplodus sargus [10] and California halibut Paralichthys californicus [11]. The sharpsnout sea bream Diplodus puntazzo (Cetti 1777) and the common pandora Pagellus erythrinus (L. 1758) are important fishery resources, occurring throughout the Mediterranean basin [12]. In addition, both species are considered as promising candidates for diversification in aquaculture due to their high market price, the possibility of reproduction in captivity, high growth rate and food conversion efficiency [13-23]. Massive production of these species is still limited because of hatchery problems with high mortalities occurring during larval rearing [24] when intensive larviculture techniques are used, particularly at transition from endogenous to exogenous feeding and weaning to artificial diets. Such problems, mainly arising from a lack of knowledge concerning nutriational requirements and feeding sequences, often result in low and unpredictable survival rates (ranging from 3 to $40 \%$ ) [25]. Larval performances improve under mesocosm rearing, resulting in better larval quality and survival. The mesocosm rearing technique, which attained $54 \%$ of larval survival [26], is known to provide more natural conditions compared

*Address correspondence to this author at the Consiglio Nazionale delle Ricerche, Istituto per l'Ambiente Marino Costiero, Spianata S. Raineri 86, 98122 Messina, Italy; Tel: +39090669003; Fax: +39090669007; E-mail: valeria.micale@iamc.cnr.it to intensive rearing techniques, as well as a more stable prey population, resulting in a better feeding and, hence, slower yolk consumption [27].

Recently, details of the development of the digestive tract of the common pandora and the sharpsnout sea bream have been reported $[28,29]$. These data contributed to clarify the process of assimilation through the development of feeding protocols matching the nutritional requirements and digestive ability of larvae, therefore leading to the improvement of larval survival in different rearing conditions. In consideration of the same environmental characteristics, the purpose of present paper is to compare the morphogenetic and histochemical data, reported from the above cited studies, to better elucidate the similarity of these two species.

\section{FEEDINGS PROTOCOLS}

The absence of a transitional starvation period between endogenous and exogenous feeding, in the species considered, such as that reported in the yellowfin porgy [30] and gilthead sea bream [6], which may be caused by a too low frequency distribution of prey or their inadequate size [31], is indicative of an adequate feeding protocol during early larval stages.

\section{Pagellus erythrinus}

Larvae of $P$. erythrinus were obtained by natural spawning from a broodstock adapted to captivity at the COISPA experimental aquaculture station (Bari, Italy). Floating eggs were incubated at $18.5-20^{\circ} \mathrm{C}$, with moderate aeration in 1.5 $\mathrm{m}^{3}$ tanks (density: $140 \times 1^{-1}$ ). The salinity of the inlet water was 34 and the $\mathrm{pH}$ 7.7. During larval rearing (initial density: $\left.110 \operatorname{larvae} \times 1^{-1}\right)$, the water turnover was 1.5 volumes $\times$ day $^{-1}$, the temperature was the same as during incubation and 
natural photoperiod (July-August in the Central Mediterranean) was applied. From the hatching day till the Artemia feeding stage, cultured microalgae Isochrysis galbana and Tetraselmis suecica were supplied as water conditioner to the rearing units, according to the pseudo-green method [32]. Starting from the $3^{\text {rd }}$ day after hatching (DAH), rotifers (Brachionus plicatilis; small strain: $129 \mu \mathrm{m}$ lorica length) enriched with the commercial emulsion DHA SELCO twice every 6 hours were also added. Average concentration of rotifers in the rearing tanks was 10 individuals $\mathrm{ml}^{-1}$. The supply of Artemia nauplii enriched with DHA SELCO started on $28 \mathrm{DAH}$. Formulated feed was introduced in the diet from 35 DAH onwards. Any change of food was applied gradually with an overlapping phase. The use of microalgae seem to be essential during the first stage of common pandora larval rearing [24] as well as of other marine larvae (e.g. S. aurata, P. pagrus). Indeed, the positive effect of microalgae was highlighted by previous studies [e.g.33], suggesting that phytoplankton may act as a diet component and/or stimulating factor of digestive enzyme synthesis. Survival at the end of metamorphosis was $6 \%$.

\section{Diplodus puntazzo}

Larval rearing using the mesocosm technique was carried out at the facilities of the Institute of Aquaculture, Hellenic Center for Marine Research in Crete, Greece. Eggs were obtained in October 2005 from natural spawning and incubated, at an initial density of 2.5 eggs per litre, in a 40 $\mathrm{m}^{3}$ semi-indoor tank initially filled with surface sea-water (salinity: 40) and subsequently supplied with water from a shallow well (salinity: 32). The daily water renewal increased progressively from $5 \%$ to $200 \%$ at 35 DAH. Aeration was provided by wooden diffusers, guaranteeing a $90-95 \%$ oxygen saturation. Water temperature started from $21.5{ }^{\circ} \mathrm{C}$ and decreased to $19.0 \pm 0.5^{\circ} \mathrm{C}$ since $7 \mathrm{DAH}$. From 3 to 38 DAH, microalgae (Chlorella minutissima) were added twice daily $\left(250-400 \times 10^{3}\right.$ cells $\left.\mathrm{ml}^{-1}\right)$. From 4 to $30 \mathrm{DAH}$, larvae were fed on rotifers enriched with a commercial emulsion (DHA Protein Selco, INVE S.A., Belgium), supplied twice daily (3-4 rotifers $\mathrm{ml}^{-1}$ ). From 18 to $53 \mathrm{DAH}$, Artemia spp. nauplii enriched with a commercial emulsion (A1 DAH Selco, INVE S.A., Belgium) were provided continuously to a concentration of 0.2 nauplii $\mathrm{ml}^{-1}$. Formulated feed of progressively larger size was provided continuously from 29 DAH onwards, by means of electrical feeders.

\section{COMPARATIVE EXTERNAL MORPHOLOGY}

Growth of common pandora and sharpsnout sea bream larvae followed an exponential curve (Fig. 1).

At hatching (TL, total length: $2.55 \pm 0.12 \mathrm{~mm}, n=40$ and $2.55 \pm 0.05 \mathrm{~mm}, n=10$ for common pandora and sharpsnout seabream, respectively), the alimentary canal appeared as a straight tube lying dorsally to the yolk sac. The anterior and posterior ends were closed. The anus opened at 2 DAH (TL: $3.05 \pm 0.15 \mathrm{~mm}, n=40$ ) and 4 DAH (TL: 3.25 $\pm 0.07 \mathrm{~mm}, n=10$ ), respectively. At $3 \mathrm{DAH}$ (TL: $3.18 \pm$ $0.10 \mathrm{~mm}, n=40)$ the mouth opened in common pandora and exogenous feeding began (few rotifer mastaxes as well as microalgae could be identified); on the other hand, in sharpsnout seabream the mouth was open at 3 DAH (TL: $3.21 \pm 0.11 \mathrm{~mm}, n=10$ ), but no food could be identified in the digestive tract until $4 \mathrm{DAH}$, when about $50 \%$ of the larvae were actively feeding. In both species, the yolk sac was almost completely reabsorbed and the eyes were pigmented by 4 DAH (TL: $3.20 \pm 0.11 \mathrm{~mm}, n=40$; TL: 3.25 $\pm 0.07 \mathrm{~mm}, \mathrm{n}=10$, for common pandora and sharpsnout seabream respectively), while the oil droplet was reabsorbed at $6 \mathrm{DAH}$ (TL: $3.34 \pm 0.12 \mathrm{~mm}, n=40$ ) and 8 DAH (TL: $3.74 \pm 0.20 \mathrm{~mm}, n=10)$, respectively. The swim bladder was inflated at $8 \mathrm{DAH}(\mathrm{TL}: 3.74 \pm 0.20 \mathrm{~mm}, n=10)$ in $100 \%$ sharpsnout seabream larvae, while it started to be inflated at $9 \mathrm{DAH}$ in common pandora.

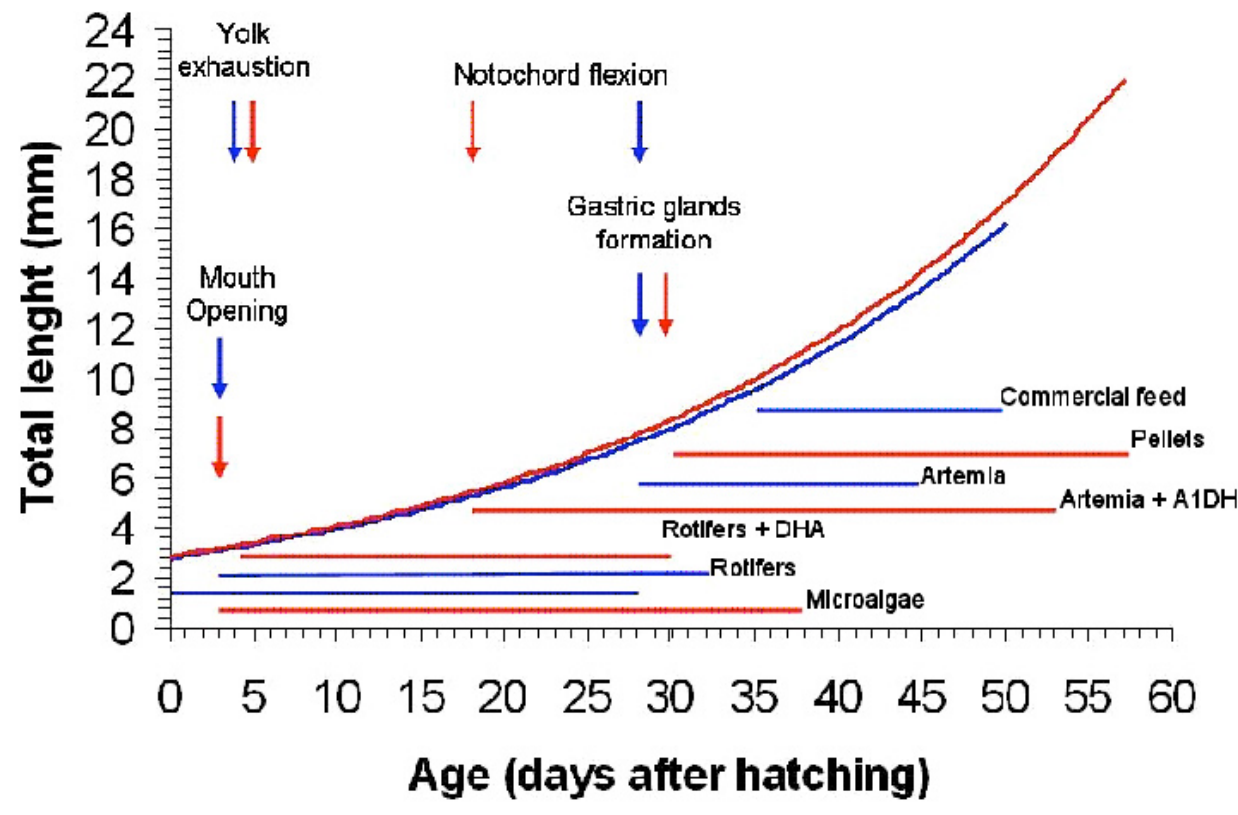

Fig. (1). Feeding protocol and growth in size of sharpsnout sea bream larvae from hatching to 57 days and common pandora larvae from hatching to 50 days. The main events of larval development schedule are also shown. Red: sharpsnout sea bream. Blue: common pandora. 


\section{COMPARATIVE DEVELOPMENT OF DIGESTIVE TRACT}

The major ontogenetic events occurring during larval development of sharpsnout seabream and common pandora are summarized in Table $\mathbf{1}$.

At hatching the alimentary canal appeared as a histologically undifferentiated straight tube lying dorsally to the yolk sac. Rapid developmental changes lead to the differenttiation of the digestive tract into four segments (i.e., buccopharinx, oesophagus, presumptive stomach and intestine) within $3 \mathrm{DAH}$ in common pandora and $2 \mathrm{DAH}$ in sharpsnout seabream. At this stage, strongly eosinophilic yolk globules were still visible in the resorbing yolk sac.

\section{Buccopharynx}

At mouth opening by $3 \mathrm{DAH}$ in both species, the oral cavity was lined by a simple squamous epithelium, while the pharynx was lined by a pseudostratified epithelium. The first goblet cells appeared, in the pharyngeal mucosa, at 5-7 DAH in sharpsnout seabream and at 9-11 DAH in common pandora, more precociously than in mouth, at 24 and 17
DAH respectively. Taste buds appeared at 11 DAH in sharpsnout seabream, earlier than in common pandora (17 DAH). Taste buds and goblet cells became more numerous as larvae grew. Mandibular and maxillar teeth erupt respectively at $57 \mathrm{DAH}$ in sharpsnout seabream and $30 \mathrm{DAH}$ in common pandora while pharyngeal teethed erupt respectively at 42- $45 \mathrm{DAH}$ and $36 \mathrm{DAH}$.

\section{Oesophagus}

In both species, at mouth opening (3 DAH) the buccopharynx, communicated with the anterior intestine through a short oesophagus with a rather narrow lumen. Two different regions could be distinguished in the oesophagus, based upon the histological features of their mucosa: an anterior region lined by a pseudostratified, (columnar in sharpsnout seabream) ciliated, epithelium, and a dilated posterior region lined by a simple, cuboidal epithelium, from which the future stomach will originate. Circular smooth muscle fibers were visible in the oesophagus wall. At 5 DAH in sharpsnout seabream goblet cells appeared scattered within the mucosal surface of the anterior oesophagus, which was expanded in several longitudinal folds. On the other hand, both goblet

Table 1. Major Events During Larval Development of Sharpsnout Sea Bream and Common Pandora.

DAH: Days After Hatching. Total Length is Expressed as Mean \pm S.D. at the Beginning of each Stage. Numbers in Brackets Indicate the Age in DAH

\begin{tabular}{|c|c|c|c|c|}
\hline Stage & DAH & $\mathbf{T L}(\mathbf{m m})$ & Feeding Mode & Histo-Morphological Observations \\
\hline Endotrophic & $\begin{array}{l}0-3 \\
0-2\end{array}$ & $\begin{array}{l}2.55 \pm 0.05 \\
2.55 \pm 0.12\end{array}$ & Endogenous & $\begin{array}{l}\text { Segmentation of gut into buccopharynx, oesophagus, stomach anlage, anterior and } \\
\text { posterior intestine [2] (3). } \\
\text { Differentiation of liver [2] (2-3), gall bladder [2] (3), exocrine and endocrine pancreas } \\
{[2](3) \text {. }} \\
\text { Mouth opening [3] (3). } \\
\text { Intestinal looping [3] (4) and early mucosal folding [3] (10). } \\
\text { Opening of biliary and pancreatic ducts into anterior intestine [3] (4). } \\
\text { Eyes pigmented [3] (4). }\end{array}$ \\
\hline $\begin{array}{c}\text { Endo- } \\
\text { exotrophic }\end{array}$ & $\begin{array}{l}4-7 \\
3-5\end{array}$ & $\begin{array}{l}3.25 \pm 0.07 \\
3.18 \pm 0.10\end{array}$ & $\begin{array}{l}\text { Endogenous and } \\
\text { exogenous }\end{array}$ & $\begin{array}{l}\text { Anus opening [4] (2). } \\
\text { Protein and glycogen in the liver [4] PAS positive granules and colourness PAS negative } \\
\text { vacuoles (11). } \\
\text { Yolk sac resorption [4] (4) } \\
\text { Protein [5] (2) and probable lipid [5] (2) vacuolization in posterior and anterior intestine, } \\
\text { respectively. } \\
\text { Goblet cells in pharynx and oesofagus [5] (11). } \\
\text { Mucosal folding of the oesophagus [5] (20). }\end{array}$ \\
\hline Exotrophic & $\begin{array}{l}8-57 \\
6-50\end{array}$ & $\begin{array}{l}3.74 \pm 0.20 \\
3.34 \pm 0.12\end{array}$ & Exogenous & $\begin{array}{c}\text { Oil drop resorption [8] (6). } \\
\text { Inflation of swim bladder [8] (9). } \\
\text { Ileo-rectal valve fully developed [10] (6). } \\
\text { Early caecal development [10] (22). } \\
\text { Bucco-pharyngeal taste buds [11] (17). } \\
\text { Notochord flexion [18] (28). } \\
\text { Goblet cells in the buccal cavity [24] (17). } \\
\text { Stomach segmentation [10] (16). } \\
\text { Formation of gastric glands [30] (28). } \\
\text { Anal and dorsal fins fully developed [33] (30). } \\
\text { Goblet cells in the intestine [33] (33). } \\
\text { Eruption of mandibular and maxillar teeth [57] (30). } \\
\text { Eruption of pharyngeal teeth [42-45] (36). }\end{array}$ \\
\hline
\end{tabular}


cells and mucosal folding appeared later in pandora (at 11 and $20 \mathrm{DAH}$, respectively). A submucosa formed by loose connective tissue, a circular muscle layer (tunica muscularis) and a thin outer serosa completed the oesophagus wall in both species.

\section{Stomach}

The presumptive stomach, lined by a simple cuboidal epithelium with basal nuclei, started to differentiate as a dilatation of the posterior oesophagus in sharpsnout seabream at $2 \mathrm{DAH}$ and in common pandora at 3 DAH. At 6 DAH (5-6 DAH in sharpsnout seabream) a primordial pyloric sphincter developed, separating the future stomach from the anterior portion of intestine.

In common pandora at $16 \mathrm{DAH}$ the stomach exhibited a pouched shape and its epithelium began to differentiate, so that cardiac, fundic and pyloric portions could be distinguished, the former lined by a simple cuboidal epithelium, the latter two by a thicker columnar epithelium. An apical brush border of microvilli lined the gastric epithelium, which was devoid of goblet cells. At this stage epithelial folds separating the cardiac from the fundic portion of the stomach began to appear. Gastric glands appeared at $28 \mathrm{DAH}$, as submucosal acinar cell aggregates, concentrated mainly in the fundic region. Simultaneously, the intestinal mucosa immediately posterior to the pyloric sphincter showed pronounced evaginations, indicating the beginning of caecal development. By this time, a muscularis mucosae, a submucosa and a muscle tunica could be clearly distinguished in the stomach, surrounded by an outer serous membrane. The musculature surrounding the pyloric sphyncter was well developed. The number of gastric glands increased significantly as larval development proceeded, so that they appeared largely diffused throughout the stomach by 41 DAH (39 DAH in sharpsnout seabream).

In sharpsnout seabream, at 5-6 DAH, the stomach epithelium close to the sphincter, from which the pyloric portion of the stomach will develop, became columnar. At this stage, the stomach appeared elongated and its mucosal surface was expanded in mainly longitudinal folds. At 10 $\mathrm{DAH}$, the intestinal mucosa immediately posterior to the pyloric sphincter showed pronounced evaginations, indicating the beginning of caecal development. By the same time, the cardiac portion of the stomach, lined by a simple cuboidal epithelium, could clearly be distinguished from the fundic and pyloric ones, both lined by a thicker columnar epithelium. The gastric epithelium appeared devoid of goblet cells. Gastric glands appeared at $30 \mathrm{DAH}$. By this time, a muscularis mucosae, a submucosa and a muscle tunica could be clearly distinguished in the stomach, surrounded by an outer serous membrane. The musculature surrounding the pyloric sphincter was well developed. Gastric glands proliferated, as larval development proceeded, in the fundic portion of the stomach, as in common pandora.

\section{Intestine}

Prior to mouth opening (2 DAH) in sharpsnout seabream and later, at the time of mouth opening (3 DAH) in common pandora, the future ileo-rectal valve began to develop and clearly separated the anterior (prevalvular) intestine from the bending posterior (postvalvular) intestine. The ileo-rectal valve appeared completely formed in common pandora at 6 $\mathrm{DAH}$, more precociously than in sharpsnout seabream (10 DAH). No histological difference was observed between the two intestinal segments, both of them showing a single epithelial layer composed of columnar cells with basal nuclei. With the beginning of exogenous feeding (3 DAH), in common pandora and in sharpsnout seabream, the lumen of the anterior intestine became dilated and loop formation (3-4 DAH) started in the anterior intestine. At $3 \mathrm{DAH}$ in sharpsnout seabream and later (10 DAH), in common pandora, primordial mucosal folding began, which appeared well developed in the anterior intestine, in common pandora by $22 \mathrm{DAH}$ and by $28 \mathrm{DAH}$ in sharpsnout seabream. Goblet cells appeared interspersed between enterocytes of both anterior and posterior intestine from $33 \mathrm{DAH}$, more numerous in sharpsnout seabream than in common pandora.

In both the species, at $48 \mathrm{DAH}$ mucosal folding of the anterior intestine appeared very prominent, whereas the posterior intestinal mucosa showed few, short folds.

\section{Liver, Pancreas and Gall Bladder}

At hatching, the accessory digestive organs were absent. At $2 \mathrm{DAH}$, the rudimentary liver and pancreas appeared in both species as a cord-like structure, lying between the intestine and the yolk sac wall close to the pancreas. The liver was constituted by irregularly shaped, basophilic cells with a round nucleus and a prominent nucleolus in common pandora, while it consisted of swollen, conspicuously vacuolized cells, with the nuclei pushed towards the periphery in sharpsnout seabream. Liver vacuolization was greatly reduced at the beginning of exogenous feeding by $4 \mathrm{DAH}$, and the mature hepatocytes appeared, as in common pandora (5 DAH), as polyhedral cells, tightly packed between sinusoids, often around a central vein, with a prominent, round nucleus and a granular, slightly vacuolar cytoplasm. From 11 DAH, in common pandora, cytoplasmic vacuoles started to appear within hepatocytes and they progressively increased with larval growth. In both species granulation and vacuolization of the cytoplasm due to synthesis and storage of nutrients increased as exogenous feeding proceeded.

At 3 DAH (2 DAH in sharpsnout seabream) the incipient pancreas could be detected lying dorsally to the yolk sac wall and ventrally to the developing gut. It was formed by exocrine polyhedral cells with round basal nuclei and a prominent nucleolus, containing dense eosinophilic zymogen granules at the apical portion of cytoplasm towards the lumen. At $2 \mathrm{DAH}$ in sharpsnout seabream but later (4 DAH) in common pandora the endocrine pancreas could already be distinguished as islets of irregularly shaped cells with a pale cytoplasm and a large, central nucleus containing granular chromatin, lying within the exocrine cells. At these precocious stage, for both species, the exocrine pancreas was proportionally very large in comparison with the last stages of larval growth. By 3 DAH in sharpsnout seabream conspicuous eosinophilic zymogen granules appeared within the exocrine cells, at the apical portion of their cytoplasm, and the main pancreatic duct was visible, opening into the anterior intestine. Later, in common pandora, at $4 \mathrm{DAH}$ pancreatic ducts were formed and the opening of the main 
pancreatic duct into the anterior intestine, just after the pyloric sphyncter, could be clearly seen.

The gall bladder was visible from 2 DAH in sharpsnout seabream and from 3 DAH in common pandora, lying between the exocrine pancreas, liver and yolk sac wall. It was lined by a squamous epithelium, which appeared flattened and thin when the bladder was distended. On the contrary the opening of the bile duct into the anterior intestine, just after the pyloric sphincter, was visible at 3 DAH in sharpsnout seabream and at 4 DAH in common pandora. At 33 DAH in sharpsnout seabream and later at 36 DAH in common pandora, the epithelium of the gall bladder appeared thickened, with cuboidal and cylindrical cells visible in the same section. A basal lamina of connective tissue containing scattered smooth muscle cells underlay the epithelium.

\section{COMPARATIVE MORPHO-FUNCTIONAL FEA- TURES}

Similarly to most marine fish, in the two considered species, larval development can be divided into three stages, based upon feeding mode: an endotrophic stage (endogenous feeding) from hatching to mouth opening; an endoexotrophic stage (mixed endogenous/exogenous feeding first feeding) lasting until complete exhaustion of yolk reserves and a strictly exotrophic stage (exclusive exogenous feeding).

The differentiation of the digestive tract into four morphologically distinct regions namely the buccopharynx, oesophagus, presumptive stomach, lined by a simple cuboidal epithelium common to the two species considered, and intestine was established, within $3 \mathrm{DAH}$, coinciding with time of first feeding in common pandora and at $2 \mathrm{DAH}$, at the end of endogenous feeding, in sharpsnout seabream. In both species first feeding occurred before complete resorption of yolk. A strictly exotrophic stage followed from $6 \mathrm{DAH}$ in common pandora and $8 \mathrm{DAH}$ in sharpsnout seabream. In this latter, the first gastric glands were formed at the accomplishment of the first month of life, as in common pandora, and a fully glandular stomach could be observed approximately ten days later. However, a sharp increase in pepsinspecific activity was delayed of about one week in sharpsnout seabream [34], compared to common pandora [35]. Gastric glands were detected more precociously, in other Sparids, such as Diplodus sargus [10], Dentex dentex [36], Pagrus pagrus [37] and Pagrus auriga [38], but considerably later in the gilthead seabream Sparus aurata [7].

The location of gastric glands is species-specific and has been related to feeding habits [10]. In $D$. puntazzo, gastric glands occurred only in the fundic region of the stomach, as was also shown in the yellowtail flounder Pleuronectes ferruginea [39], the summer flounder Paralichthys dentatus [40], the turbot Scophthalmus maximus [41] and the Dover sole Solea solea [42]. On the other hand, gastric glands were only found in the cardiac region in D. sargus [10], shi drum Umbrina cirrosa [28] and red porgy P. pagrus [37], whereas an entirely glandular stomach occurs in common pandora. Neutral mucosubstances could be detected by the PAS reaction in the gastric epithelial cells at the same time as the gastric glands and could indicate the involvement of the former in mucosa protection from auto-digestion processes caused by hydrochloric acid and the enzymes secreted by the gastric glands, as in the milkfish Chanos chanos [43] and the gilthead sea bream [7]. On the other hand, neutral glycolconjugates have also been reported in the stomach epithetlium of adult Mediterranean amberjack Seriola dumerilii [44] and larval white seabream Diplodus sargus [10], and this fact has been related to the absorption of easily digestible substances, such as disaccharides and shortchain fatty acids. Neither proteins rich in tryptophan, which have been related to pepsinogen synthesis in the amberjack $S$. dumerilii [44], nor proteins rich in cysteine, were found in the gastric glands of sharpsnout seabream, whereas they do occur in the congener species D. sargus [10]. Similarly, cysteine- and tryptophan-rich proteins have been reported in the gastric glands of $P$. pagrus [37], but not in those of $P$. auriga [45]. This would suggest that the presence of these aminoacid residues in the gastric glands of fish is speciesspecific.

The formation of the pyloric caeca has been considered in many species as the last major event during ontogeny of the digestive system in fish larvae, indicating the transition from a larval to a juvenile stage $[8,29,30,40,46]$. On the contrary, caecal development started precociously in D.puntazzo (10 DAH) and much later in P. erythrynus (22 DAH). In both species, however, caecal development preceded the formation of gastric glands, as in D. labrax [47]. In the absence of functional gastric glands, the precocious development of pyloric caeca, in which several enzymatic activities have been demonstrated [48], may enhance the digestive capability of larvae. Moreover, as the pyloric caeca have the same histological structure as the intestine, their early development increases the total available absorption area [49], ensuring a more efficient utilization of feed. Intestinal coiling began at mouth opening in both species, as in D. sargus [10] and P. auriga [45], and considerably earlier than in other Sparids studied so far [36, 37]. Folding of intestinal mucosa, which would ensure more efficient digestion and absorption processes, started much earlier in sharpsnout seabream (3 DAH) than in common pandora (10 DAH). The presence of unstained vacuoles in the anterior intestine mucosa after the beginning of exogenous feeding (4-5 DAH in the two species considered), has been described in other species as an indicator of luminal absorption and storage of lipid [6, 10, 28, 40, 45, 50-52] during the larval phase, due to poor lipid metabolism, which improves with larval growth. Simultaneously with the beginning of exogenous feeding, lipid absorption was visible in the enterocytes of the anterior intestine, as small, supraand infranuclear unstained vesicles. With the beginning of exogenous feeding (3-4 DAH), small supra- and infranuclear vacuoles could be seen in some tracts of the anterior intestinal epithelium. Such vacuoles, which were negative to both protein and carbohydrates reactions, thus suggesting lipid absorption, increased in number as the larvae grew. The small vesicles observed in the anterior intestinal epithelium, from 4 DAH onwards suggest that enterocytes are able to process and transfer the fat contents of ingested food from a very early developmental stage, unlike what happens in other freshwater and marine larvae, which exhibit large lipid droplets, suggesting a temporary storage of excess fatty acids [28-30, 52]. Protein absorption was visible shortly after first 
feeding, as supranuclear Bromophenol blue-positive vacuoles occurring in the enterocytes of posterior intestine. These vacuoles, which have been described in the posterior intestine of both larval and adult gastric and agastric fish [53, 54], are involved in the pinocytotic uptake of proteins, which are subsequently digested intracellularly [55]. In some teleosts, they are present only until formation of the gastric glands, suggesting a transient mechanism for protein digestion, related to the immaturity of the digestive tract [7, $10,28,56,57]$. Since no reduction in the number of protein vacuoles was observed after a glandular stomach was formed, similarly to what has been reported in the European sea bass [47] it can be suggested that a combined intra- and extracellular protein digestion mechanism is active in the two species considered.

Goblet cells appeared in the digestive tract after the first exogenous feeding, and their number increased with larval development. The time at which mucus secreting cells are formed varies among species, although their sequence of appearance along the different segments of digestive tract (i.e. firstly, oesophagus, secondly, buccal cavity, and finally, intestine) is common to many examined species $[10,36,45$, 47]. Glycoproteins produced by goblet cells may play an important lubricant role of the buccopharyngeal and oesophageal mucosa, which lack salivary glands. Mucosubstances may also play a role in protecting the digestive mucosa from bacterial and viral attacks [11], as well as in pre-gastric digestion [39]. The mucous content of goblet cells in sharpsnout seabream varied with the digestive region and, in some cases, with the developmental phase. Variability in staining within a given goblet cell has been attributed to a temporal sequence in the mucus biosynthesis [58], from an early developmental stage during which the cell produces mainly PAS-positive neutral glycoproteins, through an intermediate stage during which carboxylation of the glycoproteins occur, until a final stage, when sulphated groups are conjugated to the glycoproteins. In sharpsnout seabream, pharyngeal goblet cells secreting acid sialomucins appeared at $5 \mathrm{DAH}$ and their mucous content did not vary in the later stages. Acid mucins were also abundant in oesophageal goblet cells after $7 \mathrm{DAH}$, but these cells contained sulphated mucins ten days later as well as cystein-rich proteins thirteen days later. On the other hand, the goblet cells of buccal cavity, which were first visible at $24 \mathrm{DAH}$, were shown to contain neutral mucins at $31 \mathrm{DAH}$ and sulphated mucins from 36 DAH. Finally, two types of goblet cells appeared in the intestinal epithelium coinciding with formation of gastric glands, one containing neutral mucins and the other one containing acid mucins. These data suggest that the variable staining of digestive goblet cells in $D$. puntazzo may be related to a progressive development of the mucus content in both the buccal cavity and oesophagus, but not in the pharynx and intestine.

At mouth opening (3 DAH) the gall bladder, liver and pancreas were already differentiated and connected to the intestine by the bile and main pancreatic duct, respectively. Eosinophilic zymogen granules, where the precursors of pancreatic enzymes are accumulated, could be detected within the exocrine pancreatic cells, suggesting their genetically programmed, rather than dietary-induced, differentiation $[5,11,59]$.
In common pandora the colourless, PAS-negative liver vacuoles, which increased progressively during larval development, are indicative of lipid storage, whereas in sharpsnout seabream, the large, unstained vacuoles of probable lipid origin, were reduced at the beginning of the endoexotrophic stage. It could be suggested that, in the last species, lipid from yolk reserves accumulated by the liver before mouth opening was almost exhausted at transition from endogenous to exogenous feeding, as has been reported in other species [52].

\section{REFERENCES}

[1] Blaxter JHS, Danielssen D, Moksness E, Øiestad V. Description of the early development of the halibut Hippoglossus hippoglossus and attempts to rear the larvae past first feeding. Mar Biol 1983; 73: $99-107$.

[2] Cousin JCB, Baudin Laurencin F. Morphogenèse de l'appareil digestif et de la vessie gazeuse du turbot Scophthalmus maximus L. Aquaculture 1985; 47: 305-19.

[3] Kjørsvik E, van der Meeren T, Kryvi H, Arnfinnson J, Kvenseth PG. Early development of the digestive tract of cod larvae, Gadus morhua L., during start-feeding and starvation. J Fish Biol 1991; 38: 1-15.

[4] Boulhic M, Gabaudan J. Histological study of the organogenesis of the Digestive system and swim bladder of the Dover sole Solea solea (Linnaeus 1758). Aquaculture 1992; 102: 373-96.

[5] Ribeiro L, Sarasquete C, Dinis MT. Histological and histochemical development of the digestive system of Solea senegalensis (Kaup, 1858) larve. Aquaculture 1999; 171: 293-308.

[6] Sarasquete MC, Polo A, Yúfera M. Histology and histochemistry of the development of the digestive system of larval gilthead seabream, Sparus aurata L. Aquaculture 1995; 130: 79-92.

[7] Elbal MT, García Hernández MP, Lozano MT, Agulleiro B. Development of the digestive tract of gilthead sea bream (Sparus aurata L.). Light and electron microscopic studies. Aquaculture 2004; 234: 215-38.

[8] Hamlin HJ, Hunt von Herbing I, Kling LJ. Histological and morphological evaluations of the digestive tract and associated organs of the haddock throughout post-hatching ontogeny. J Fish Biol 2000; 57: 716-32.

[9] Gordon AK, Hecht T. Histological studies on the development of the digestive system of the clownfish Amphiprion percula and the time of weaning. J Appl Ichthyol 2002; 18: 113-7.

[10] Ortiz-Delgado JB, Darias MJ, Cañavate JP, Yúfera M, Sarasquete C. Organogenesis of the digestive tract in the white seabream, Diplodus sargus. Histological and histochemical approaches. Histol Histopathol 2003; 18: 1141-54.

[11] Gisbert E, Piedrahita RH, Conklin DE. Ontogenetic development of the digestive system in California halibut (Paralichthys californicus) with notes on feeding practices. Aquaculture 2004; 232: 455-70.

[12] Spedicato MT, Greco S, Sophronidis K, Lembo G, Giordano D, Argyri A. Geographical distribution, abundance and some population characteristics of the species of the genus Pagellus (Osteichthyes: Perciformes) in different areas of the Mediterranean. Sci Mar 2002; 66(Suppl 2): 65-82.

[13] Cejas J, Jerez S, Santamaria F, Samper M. Estudios preliminares de la reproduccion y cultivo larvario de la breca (Pagellus erythrinus) en cautividad. Actas IV Congreso Nacional de Acuicultura 1993; pp. 61-5.

[14] Klaoudatos SD, Iakovopoulos G, Klaoudatos DS. Pagellus erythrinus (common pandora) a promising species for enlargement of the aquaculture production diversification. In: Basurco B, Saroglia M, Eds. Seafarming. Today and tomorrow. Oostende: European Aquaculture Society Special Publication 2002; 32: pp. 278-279.

[15] Faranda F, Cavaliere A, Lo Paro G, Manganaro A, Mazzola A. Preliminary studies on reproduction of Puntazzo puntazzo (Gmelin, 1789) (Pisces: Sparidae) under controlled conditions. Aquaculture 1985; 49: 111-23. 
[16] Caggiano M, Canese S, Lupo A, Cirillo A. Experiences of artificial reproduction and larval rearing of sheepshead bream (Diplodus puntazzo) in the South of Italy. In: Carrillo M, Dahle L, Morales J, Sorgeloos P, Svennevig N, Wyban J, Eds. From Discovery to Commercialization. World Aquaculture '93, Ghent, European Aquaculture Society Special Publication 1993; vol. 19: p. 326.

[17] Greco S, Lo Paro G, Caridi D, et al. Controlled spawning and larval development in the sharpsnout seabream (Diplodus puntazzo, Sparidae), Oostende: European Aquaculture Society Special Publication 1993; vol. 18: pp. 185-8.

[18] Favaloro E, Lopiano D, Mazzola A. Rearing of sharpsnout seabream (Diplodus puntazzo, Cetti 1777) in a Mediterranean fish farm: monoculture versus polyculture. Aquacult Res 2002; 33: 13740.

[19] Hernández MD, Egea MA, Rueda FM, Martinez FJ, Garcia Garcia B. Seasonal condition and body composition changes in sharpsnout seabream (Diplodus puntazzo) raised in captivity. Aquaculture 2003; 220: 569-80.

[20] Divanach P, Kentouri M. Utilisation des techniques extensives pour la production à grande échelle d'alevins de sar Puntazzo puntazzo. C R Acad Sci Paris 1982; 294(3): 1017-9.

[21] Divanach P, Kentouri M. Hatchery techniques for specific diversification in Mediterranean finfish larviculture. Cah Options Méditerr 2000; 47: 75-87.

[22] Franicevic V. Improvements in intensive rearing of Puntazzo puntazzo (Gmelin 1789) (Pisces, Sparidae) larvae. In: Billard R, De Pauw N, Eds. Aquaculture Europe '89, Ghent: European Aquaculture Society Special Publication 1989; vol. 10: pp. 103-4.

[23] Gatland P. Growth of Puntazzo puntazzo in cages in Selonda bay, Corinthos, Greece. Cah Options Méditerr 1995; 16: 51-5.

[24] Spedicato MT, Contegiacomo M, Carbonara P, Lembo G. Sistemi di produzione innovativi orientati alla maricoltura di nuove specie: Pagellus erythrinus, Pagellus bogaraveo. Biol Mar Medit 1998; 5: 1180-5.

[25] Marangos C. Larviculture of the sheepshead bream, Puntazzo puntazzo (Gmelin 1789) (Pisces Sparidae). Cah Options Méditerr 1995; 16: 41-6.

[26] Papandroulakis N, Kentouri M, Maingot E, Divanach P. Mesocosm: a reliable technology for larval rearing of Diplodus puntazzo and Diplodus sargus sargus. Aquacult Int 2004; 12: 345 55.

[27] Reitan KI, Rainuzzo JR, Øie G, Olsen Y. Nutritional effects of algal addition in first-feeding of turbot (Scophtalmus maximus L.) larvae. Aquaculture 1993; 118: 257-75.

[28] Zaiss MM, Papadakis IE, Maingot E, Divanach P, Mylonas CC. Ontogeny of the digestive tract in shi drum (Umbrina cirrosa L.) reared using the mesocosm larval rearing system. Aquaculture 2006; 260: 357-68.

[29] Micale V, Garaffo M, Genovese L, Spedicato MT, Muglia U. The ontogeny of the alimentary tract during larval development in common pandora Pagellus erythrinus L. Aquaculture 2006; 251: 354-65.

[30] Micale V, Di Giancamillo A, Domeneghini C, et al. Ontogeny of the digestive tract in sharpsnout sea bream Diplodus puntazzo (Cetti, 1777). Histol Histopathol 2008; 23: 1077-91.

[31] Leu MY, Chou YH. Induced spawning and larval rearing of captive yellowfin porgy, Acanthopagrus latus (Houttuyn). Aquaculture 1996; 143: 155-66.

[32] Parra G, Yúfera M. Feeding, physiology and growth responses in first-feeding gilthead seabream (Pagrus aurata L.) larvae in relation to prey density. J Exp Mar Biol Ecol 2000; 243: 1-15.

[33] Papandroulakis N, Divanach P, Anastasiadis P, Kentouri M. The pseudo-green water technique for intensive rearing of sea bream (Sparus aurata) larvae. Aquacult Int 2001; 9: 205-16.

[34] Suzer C, Aktülün S, Çoban D, Kamacı HO, Saka S, Fırat K, Alpbaz A. Digestive enzyme activities in larvae of sharpsnout seabream (Diplodus puntazzo). Comp Biochem Physiol A 2007; 148: 470-7.

[35] Caruso G, Genovese L, Micale V, Spedicato MT, Mancuso M. Preliminary investigation of the digestive enzymes in Pagellus erythrinus (Linnaeus 1758) larvae. Mar Freshw Behav Physiol 2001; 34: 265-8.

[36] Santamaría CA, Marín de Mateo M, Traveset R, et al. Larval organogenesis in common dentex Dentex dentex L. (Sparidae): histological and histochemical aspects. Aquaculture 2004; 237 : 207-28.

[37] Darias MJ, Ortiz-Delgado JB, Sarasquete C, Martínez-Rodríguez G, Yúfera M. Larval organogenesis of Pagrus pagrus L., 1758 with special attention to the digestive system development. Histol Histopathol 2007; 22: 753-68.

[38] Sánchez-Amaya MI, Ortiz-Delgado JB, García-López Á, Cárdenas $\mathrm{S}$, Sarasquete MC. Larval ontogeny of redbanded seabream Pagrus auriga Valenciennes, 1843 with special reference to the digestive system. A histological and histochemical approach. Aquaculture 2007; 263: 259-79.

[39] Baglole CJ, Murray HM, Goff GP, Wright GM. Ontogeny of the digestive tract during larval development of the yellowtail flounder: a light microscopy and mucus histochemical study. J Fish Biol 1997; 51: 120-34.

[40] Bisbal GA, Bengston DA. Development of the digestive tract in larval summer flounder. J Fish Biol 1995; 47: 277-91.

[41] Segner H, Storch V, Reinecke M, Kloas W, Hanke W. The development of functional digestive and metabolic organs in turbot Scophthalmus maximus. Mar Biol 1994; 119: 471-86.

[42] Veggetti A, Rowlerson A, Radaelli G, Arrighi S, Domeneghini C. Post-hatching development of the gut and larval muscle in the sole. J Fish Biol 1999; 55: 44-65.

[43] Ferraris RP, Tan JD, De La Cruz MC. Development of the digestive tract of milkfish, Chanos chanos (Forsskal): Histology and histochemistry. Aquaculture 1987; 61: 241- 57.

[44] Grau A, Crespo S, Sarasquete MC, Gonzáles de Canales ML. The digestive tract of the amberjack Seriola dumerilii, Risso: a light and scanning electron microscope study. J Fish Biol 1992; 41: 287-303.

[45] Hachero-Cruzado I, Ortiz-Delgado JB, Borrega B, Herrera M, Navas JI, Sarasquete C Larval organogenesis of flatfish brill Scophthalmus rhombus L: Histological and histochemical aspects. Aquaculture 2009; 286: 138-49.

[46] Chen BN, Qin JG, Kumar MS, Hutchinson W, Clarke S. Ontogenetic development of the digestive system in yellowtail kingfish Seriola lalandi larvae. Aquaculture 2006; 256: 489-501.

[47] García-Hernández MP, Lozano MT, Elbal MT, Agulleiro B. Development of the digestive tract in sea bass (Dicentrarchus labrax L.). Light and electron microscopic studies. Anat Histol Embryol 2001; 173: 1-19.

[48] Cousin JCB, Baudin-Laurencin F, Gabaudan J. Ontogeny of enzymatic activities in fed and fasting turbot, Scophthalmus maximus L. J Fish Biol 1987; 30: 15-33.

[49] Houssain AM, Dutta XM. Assessment of structural and functional similarities and differences between caeca of the bluegill. J Fish Biol 1998; 53: 1317-23.

[50] Deplano M, Diaz JP, Connes R, Kentouri-Divanach M, Cavalier F. Appearance of lipid-absorption capacities in larvae of the sea bass Dicentrarchus labrax during transition to the exotrophic phase. Mar Biol 1991; 108: 361-71.

[51] Kjørsvik E, van der Meeren T, Kryvi H, Arnfinnson J, Kvenseth PG. Early development of the digestive tract of cod larvae, Gadus morhua L., during start-feeding and starvation. J Fish Biol 1991; 38: 1-15.

[52] Diaz JP, Guyot E, Vigier S, Connes R. First event in lipid absorption during post-embryonic development of the anterior intestine in the gilt-head sea bream. J Fish Biol 1997; 51: 180-92.

[53] Krementz AB, Chapman G.B. Ultrastructure of the posterior half of the intestine of the channel catfish, Ictalurus punctatus. J Morphol 1975; 145: 441-82.

[54] Albertini-Berhaut J. L'intestin chez les Mugilidae (Poissons; Téléostéens) à différentes étapes de leur croissance. I - Aspects morphologiques et histologiques. J Appl Ichthyol 1987; 3: 1-12.

[55] Sire MF, Vernier JM. Intestinal absorption of protein in teleost fish. Comp Biochem Physiol 1992: 103A: 771-81.

[56] Tanaka M. Studies on the structure and function of the digestive system in teleost larvae. V. Epithelial changes in the posterior gut and protein ingestion. Jpn J Ichthyol 1972; 19: 172-80.

[57] Luizi FS, Gara B, Shields RJ, Bromage NR. Further description of the development of the digestive organs in Atlantic halibut (Hippoglossus hippoglossus) larvae, with notes on differential absorption of copepod and Artemia prey. Aquaculture 1999; 176: 101-16. 
[58] Harrison JD, Auger DW, Paterson KL, Rowley PSA. Mucin histochemistry of submandibular and parotid salivary glands of man: light and electron microscopy. Histochem J 1987; 19: 555-64.
[59] Zambonino-Infante JL, Cahu CL. Influence of diet on pepsin and some pancreatic enzymes in sea bass (Dicentrarchus labrax) larvae. Comp Biochem Physiol 1994; 109A: 209-12.

Received: April 13, 2010

(C) Micale and Muglia; Licensee Bentham Open.

This is an open access article licensed under the terms of the Creative Commons Attribution Non-Commercial License (http://creativecommons.org/licenses/by$\mathrm{nc} / 3.0 /$ ), which permits unrestricted, non-commercial use, distribution and reproduction in any medium, provided the work is properly cited. 